\title{
Calendar
}

To list an event in the Calendar, contact Julia Phillips, A T\& T Bell Laboratories, 600 Mountain Avenue IE-431, Murray Hill, NJ 07974; telephone (201) 582-4428.

MIRIS indicates the meeting is sponsored by or affiliated with the Materials Research Society.

\section{MARCH 1986}

2-6 AIME Annual Meeting.

New Orleans, LA.

TMS, 420 Commonwealth Dr., Warrendale, PA 15086.

9-14 SPIE Symposium on

Microlithography.

Santa Clara, CA.

SPIE Technical Program

Committee, P.O. Box 10,

Bellingham, WA 98227-0010;

(206) 676-3290.

14 Short Course on Modern

Experimental Techniques in

Materials Research.

Atlantic City, NJ

Prof. D. D. L. Chung, Dept. of

Metallurgical Eng. \&c Mat. Sci.,

Carnegie-Mellon University,

Pittsburgh, PA 15213; (412) 5782710.

22-25 Conference of the Condensed Matter Division of the European Physical Society.

Stockholm, Sweden.

G. Grimvall, Dept. of Theoretical

Physics, Royal Inst. of

Technology, S-100 44 Stockholm, Sweden.

24-28 Fourth Int1 Symposium on Design of New Materials.

College Station, TX.

A. Clearfield, Dept. of Chemistry.

Texas A\&M Univ., College

Station, TX 77843;

(409) 845-9696

31-4 General Meeting of the APS.

Las Vegas, CA.

$W$. W. Havens, 335 E. 45th St.,

New York, NY 10017

31-5 Optical Society of America 1986

Spring Meeting.

Honolulu, Hawaii

OSA, 1816 Jefferson Pl., N.W.

Washington, DC 20036
APRIL 1986

6-11 International Conference on Metallurgical Coatings.

San Diego, CA.

H. A. Beale, Applied Coatings

International, 775 Kaderly Dr.,

Columbus, $\mathrm{OH} 43228$

7-10 MRS Low Energy lon

Beams-4.

Brighton, England.

The Institute of Physics, 47

Belgrave Square, London

SW1X 8QX, England;

01-235-6111.

(See related article in Vol. $X$ No. 5.)

8-10 31st National SAMPE

Symposium-Materials Science

for the Future.

Las Vegas, NV.

Marge Smith, SAMPE, P.O. Box

2459, Covina, CA 91722: (818)

331-0616.

13-18 American Chemical Society

General Meeting.

New York, NY.

American Chemical Society, 1155

16th St., N.W., Washington, DC

20036.

15-18 M|R/S Spring Meeting of the

Materials Research Society.

Palo Alto, CA.

J. B. Ballance,

Materials Research Society,

9800 McKnight Rd., Suite 327.

Pittsburgh, PA 15237;

(412) 367-3003.

(See related article in this issue.)

21-22 Short Course on Micro-Analytical Techniques in Materials Science.

Washington, D.C.

Carl J. Arbes, 5169 11th Street, S., Arlington, VA 22204.

27-1 American Ceramic Society General

Meeting.

Chicago, IL

American Ceramic Society, 65

Ceramic Dr., Columbus, OH 43214.

\section{MAY 1986}

-2 MISS Semiconductor Based Heterostructures: Interface Structure and Stability (1986 TMS Northeast Regional

Conference).

Murray Hill, NJ.

Martin L. Green, AT\&T Bell

Laboratories, Murray Hill, N]; (201) 582-3000.

(See related article in Vol. X No, 5)

4-9 Spring Meeting of the Electrochemical Society. Boston, MA

Electrochemical Society, 10 S. Main St., Pennington, N] 08534-2896.

4-9 Fifth International Symposium on Silicon Materials Science \& Technology.

Boston, MA

H. R. Huff, Monsanto Electronic Materials Company, 755 Page Mill Rd. P.O. Box 10123, Palo Alto, CA 94303.

5-8 18th Annual Offshore

Technology Conference.

Houston, TX.

TMS, 420 Commonwealth Dr. Warrendale, PA 15086.

11-16 13th Congress of the Council of Mining \& Metallurgical Institutions.

Canberra, Australia. TMS, 420 Commonwealth Dr. Warrendale, PA 15086.

12-15 Workshop on Refractory Metals \& Silicides for VLSI. San Juan Bautista, CA. Continuing Education in Engineering, Univ. Extension, Univ. of CA, 2223 Fulton St., Berkeley, CA 94720.

25-30 International Symposium on the Properties \& Applications of Metal Hydrides V. Maubuisson, France.

G. G. Libowitz, Allied Corp., P.O. Box 1021R, Morristown, NJ 07960; (201) 455-3583. 
27-30 International Conference on

Composite Interfaces.

Cleveland, $\mathrm{OH}$.

H. Ishida, Dept. of

Macromolecular Sci., Case

Western Reserve Univ.

Cleveland, $\mathrm{OH} 44106$;

(216) 368-4 285

\section{JUNE 1986}

SPIE International Symposium on Optical \& Optoelectronic Applied Sciences \& Engineering.

Quebec City, Canada.

SPIE Technical Program

Comm./1986 Quebec Symp., P.O.

Box 10, Bellingham, WA 98227-

0010; (206) 676-3290.

9-13 MRS International Conference on Ion Beam Modification of Materials.

Catania, Italy.

E. Rimini, Depart. of Physics,

Corso Italia 57, 195129 Catania, Italy.

9-13 OSA/IEEE Conference on Laser \& Electro-Optics (CLEO '86).

San Francisco, CA.

Optical Society of America, 1816

Jefferson PI., N.W., Washington,

DC 20036.

9-13 International Conference on

Quantum Electronics.

San Francisco, CA.

Optical Society of America, 1816

Jefferson PI., N.W., Washington,

DC 20036; (202) 223-0920.

10-12 7th International SAMPE

European Chapter Conference \&

Exhibition.

Munich, Germany.

SAMPE, 843 West Glentana (Box

2459), Covina, CA 91722;

(818) 331-0616

(See related article in Vol. $X$ No. 5. )

16-20 International Conference \&

Exhibition on Catalysts \& Surface

Effects.

San Francisco, CA

TMS, 420 Commonwealth Dr.,

Warrendale, PA 15086

23-27 World Congress on High Tech

Ceramics.

Milan, Italy.

6th CIMTEC, P.O. Box 174,

48018 Faenza, Italy;

(0546) 46147

(See related article in Vol. $X$ No. 5.)

25-27 28th Annual Electronic Materials

Conference.

Amherst, MA

TMS, 420 Commonwealth Dr.

Warrendale, PA 15086
30-2 Portland International

Conference and Exposition on

Silicon Materials and Technology.

Portland, $O R$.

Len Forbes, Dept. of Electrical and

Computer Engineering, Corvallis,

OR 97331; (503) 754-3617.

JULY 1986

5-12 6th International Summer School on Crystal Growth.

Edinburgh, Scotland.

ISS GC-6, Garber Travel, P.O.

Box 404, Dept. 91-1616,

Brookline, MA 02146;

(617) 787-0600.

7-11 Fifth International Conference on Surface Modification of Metals of lon Beams.

Kingston, Ontario.

J. L. Whitton, Physics Dept

Queens Univ., Kingston, ONT

K7L 3N6; (613) 547-2746.

13-18 8th International Crystal Growth Conference.

York, England.

ICCG-8, Garber Travel, P.O. Box

404, Dept. 91-1616, Brookline,

MA 02146; (617) 787-0600.

14-18 Scanning Tunneling Microscopy

'86.

Santiago de Compostela, Spain.

R. C. Jaklevic, Ford Motor Co.,

P.O. Box 2053, Scientific

Research Lab, Room S-3012,

Dearborn, MI 48121;

(313) 322-7554.

(See related article in this issue.)

28-31 International Conference on

Ceramic Microstructures '86: Role of Interfaces.

University of California,

Berkeley, CA.

Joseph A. Pask, Dept. of Materials

Science and Mineral Engineering,

University of California, Berkeley,

CA 94720; (415) 642-3801.

(See related article in Vol. $X$ No. 5. )

28-31 Sixth International Conference on Ion Implantation.

Berkeley, CA.

Continuing Education in

Engineering, Univ. Extension,

Univ. of CA, 2223 Fulton St.,

Berkeley, CA 94720;

(415) 642-4151.

28-1 Second International Conference on Shallow Impurity Centres.

Trieste, Italy.

Prof. R. Resta, SISSA Strada

Costiera 11, 34014 Trieste, Italy;

telephone (040) 224118

telex 460392 IC TP I.
AUGUST 1986

3-6 Conference on Ceramic Powder Science \& Technology.

Boston, MA.

American Ceramic Society, 65

Ceramic Dr., Columbus, $\mathrm{OH}$.

4-8 11th Triennial Congress on $X-$ Ray Optics and Microanalysis. London, Ontario, Canada.

J. D. Brown, Faculty of Engineering Sciences, University of Western Ontario, London, Ontario, Canada N6A 5B9;

(519) 679-3317.

10-13 International Conference on LowEnergy Dislocation Structures.

Charlottesville, VA.

D. Murdaugh, Dept. of

Conferences \& Institutes, Div. of

Continuing Education, P.O. Box

3697, 104 Midmont Ln.,

Charlottesville, VA 22903.

(804) 924-7141.

11-15 Electron Microscopy Society of America Annual Meeting.

Albuquerque, NM.

L. W. Hobbs, MIT, Dept. of Mat. Sci. and Engineering, Room 134066, Cambridge, MA 02139; (617) 253-6835.

11-15 18th International Conference on the Physics of Semiconductors. Stockholm, Sweden.

S. T. Pantelides, ICPS-18 Program Subcommittee Chairman, IBM T J. Watson Research Center, P.O. Box 218, Yorktown Heights, NY 10598; (914) 945-3000.

17-20 Second International Conference on Superlattices, Microstructures and Microdevices.

Goteborg, Sweden.

T. Andersson, Dept. of Physics, Chalmers Univ. of Technology, S-412 96 Goteborg, Sweden (46)-31810100 ext. 2122

17-22 30th Annual Symposium on Optical \& Electro-Optical Engineering.

San Diego, CA.

SPIE, P.O. Box 10, Bellingham, WA 98227-0010; (206) 676-3290.

18-22 14th International Conference on Defects in Semiconductors.

Paris, France.

D. Stievenard, Secretary ICDS 14, ISEN, 3 rue Francois Baës, 59046, Lille, France.

International Conference \& Exhibition on Engineering Ceramics.

Buffalo, NY. TMS, 420 Commonwealth Dr. Warrendale, PA 15086. 


\title{
Fly Ash and Coal Conversion By-Products: Characterization, Utilization and Disposal I
}

\author{
Edited by Gregory J. McCarthy \\ and Robert J. Lauf
}

Proceedings of the Symposium held at the 1984 MRS Fall Meeting contains 24 papers which explore analysis and handling of fly ash and consider environmental consequences and potential future uses of the material in industrial or civil engineering applications.

Topics:

- Characterization of fly ash and its reactions in concrete

- Transmitted and reflected visible light microscopy of two bituminous fly ashes

- Scanning electron microscopy and x-ray diffraction analysis of various size fractions of fly ash

- Electrokinetic phenomena and surface characteristics of fly ash particles

- Technical note on the determination of free lime $(\mathrm{CaO})$ in fly ash

- Characterization of cyrstalline phases in fly ash by microfocus Raman spectroscopy

- Characterization of catalyzed devitrification in quenched fly ash melts

- Retardation effects in the hydration of cement-fly ash pastes

- Reactions products in fly ash concrete

- Autoclave expansion of Portland cement-fly ash pastes

- Effects of fly ash and superplasticizers on the rheology of cement slurries

- Flexural strength and fracture properties of a fly ash blended cement

- Properties and potential uses of the products resulting from the fluidized bed combustion of coal washery wastes

- Utilization of fly ash in roadbed stabilization-some examples of western U.S. experience

- Utilization of fly ash in oil and gas well cementing applications

- Potential resources for coal fly ash

- Characterization of a lignite ash from the METC Gasifier-mineralogy, scanning electron microscopy, and correlations of leaching behavior and mineralogy

- Comparative economics of several alternatives for bulk utilization of fly ash and coal gasification ash

- Disposal of western fly ash in the Northern Great Plains

- Mobility of organic and inorganic constituents from energy and combustion-related wastes under codisposal conditions

- Investigation of leachability of subbituminous fly ash enhanced road based materials

- Technical review of the Energy Authority Coal Waste Artificial Reef Program (C-WARP)

Order Code: 43 MRS Members: \$20 U.S. Nonmembers \$30 Foreign Nonmembers \$36

Prepayment Required.

Send payment to:

Materials Research Society

9800 McKnight Road, Suite 327

Pittsburgh, PA 15237

telephone (412) 367-3012.

Coming in Early 1986: Fly Ash and Coal Conversion By-Products: Characterization, Utilization and Disposal II 